\title{
The preoperative assessment: who is responsible?
}

John B. Kitts MD FRCPC

$\mathrm{U}$

NTIL recently, the pre-anaesthetic assessment consisted of the traditional "night before" visit by the anaesthetist. Advances in medical technology and shrinking healthcare funds have led to the exponential growth of ambulatory surgery and day of surgery admissions. As more complex patients present for more invasive procedures on the day of surgery, there are increasing concerns about patient care, and inefficiencies in the operating room schedule. Anaesthetists are now in the unenviable position of either lowering the standard of care, or changing the way they practice. As a result, preadmission clinics (PACs) have evolved with a mandate to improve preoperative preparation of surgical patients and increase efficiencies in the surgical suites, while minimising expensive patient days in hospital. Unfortunately, there is no prototype PAC and there are almost as many models as there are clinics in existence. Since their development however, a number of key issues and concerns have arisen. Without question, the most sensitive and controversial of these is: who is responsible for the preoperative assessment?

In this issue of the Journal, Shearer $e t a l^{1}{ }^{1}$ describe a process where preoperative assessments are directed by non-anaesthetist general practitioners. These physicians are responsible for assessment and triage of patients scheduled for elective surgery in a 280-bed teaching hospital. Nurse practitioners, ${ }^{2}$ general internists, ${ }^{3}$ and anaesthetists ${ }^{4,5}$ have also been described in the literature as playing key roles in the preoperative assessment process. Clearly, there is no consensus as to which healthcare professionals are best-suited for this task.

To address the issue of who is responsible for preoperative assessments, one must clearly define the objectives. First, the preoperative assessment is a means by which the healthcare professional acquires pertinent medical information (patient history and medical documents), consultations and laboratory tests, to determine whether the peri-operative period poses an increased risk of morbidity or mortality for the patient. ${ }^{6}$ Second, guided by the risk factors identified, the patient's medical condition must be optimised and an appropriate perioperative care plan developed. Finally, the preoperative assessment should reduce patient anxiety by educating the patient about choices of anaesthesia, intra-operative care and post-operative pain management. ${ }^{6}$ Perioperative risk is a function of the preoperative medical condition of the patient, the invasiveness of the surgical procedure, and the type of anaesthetic technique administered. $^{7}$ The healthcare professional responsible for identifying increased risk must be aware of, and able to identify, medical conditions that may lead to increased peri-operative morbidity or mortality. They must also be able to determine when these conditions require further investigations, therapy or consultations with other medical disciplines. Similarly, the healthcare professional completing the preoperative assessment must be familiar with the trespass of the surgical procedure and the pathophysiological changes that result from the surgery and anaesthetic; particularly related to the respiratory, cardiovascular and central nervous systems. Finally, the risks of morbidity and mortality inherent to the anaesthetic itself, must be identified and minimised.

Because all patients presenting for surgery do not require a preoperative assessment, the focus of research in this area is directed toward development of appropriate screening procedures to identify those patients who do require evaluation by an anaesthetist prior to the day of surgery. At present there is no screening mechanism applicable to all types of anaesthetic practice. The ideal screening mechanism would identify all patients who require a preoperative assessment and exclude those who do not. With the introduction of ambulatory surgery in the early 1980s, anaesthetists agreed that an appropriate standard of care for healthy patients undergoing minor surgery, would be met by a preoperative assessment performed by the attending anaesthetist on the day of surgery. The surgeon was responsible for ensuring that the appropriate lab tests and a history and physical examination were present on the patient's file preoperatively. This practice was, and still is acceptable for bealtby patients undergoing minor procedures. In 
fact, the introduction of PACs must not be interpreted as an appropriate venue to now perform a "history and physical" on all patients presenting for surgery. This would clearly be an abuse of healthcare funds by shifting the responsibility for the patient's history and physical examination from the surgeon to other healthcare professionals; at an added cost to the system. However, patients with health problems and/or those undergoing major surgery do require a preoperative assessment before the day of surgery. Because surgical house-staff are no longer able to complete the admission history and physical examination, a considerable number of anaesthetists have incorrectly assumed that the preoperative assessment is simply a "history and physical for the surgeon." For this reason, many anaesthetists have refused to be involved in PACs. The preoperative assessment, however, is a focused assessment to address issues relevant to the safe administration of anaesthesia and performance of surgery. A history and physical examination by other healthcare professionals does not constitute clearance for the administration of anaesthesia. ${ }^{7}$

The concerns about the history and physical examination stem from hospital laws and statutes regarding patient care. Each province has its own Laws and Statutes governing medical practice and physicians and surgeons should be familiar with those in their own province; particularly as they pertain to the recent imposed changes in their practice. In Ontario, the Public Hospitals Act mandates that:

"Every Board shall ensure that a physician (a) takes a medical history, (b) gives the patient a physical examination and (c) makes a provisional diagnosis of the patient's medical condition and (d) records it on the patient's file within 72 hours after a patient is admitted to hospital. ${ }^{8}$ "

"No surgeon shall perform a surgical operation on a patient unless the surgeon, (a) performs a physical examination of the patient sufficient to enable the surgeon to make a diagnosis; and (b) ... enters ... on the medical record of the patient, a statement of the findings on the physical examination and the diagnosis."

"No person shall administer a general, spinal or epidural anaesthetic or an intravenous anaesthetic or a regional nerve block other than a mandibular nerve block for dental procedures to a patient or an outpatient unless, (a) a history of the present disability or disease or any previous medical history relevant to the disability or disease of the patient; ... (c) findings of a physical examination of the patient; and (d) the results of any laboratory tests considered necessary by the attending physician or attending dentist with respect to the patient are entered in the medical record of the patient." ${ }^{8} \mathrm{In}$ addition, "No person shall administer a general, spinal or epidural anaesthetic or an intravenous anaesthetic or a regional nerve block other than a mandibular nerve block for dental procedures, to a patient unless the anaesthetist has (a) taken a medical history and made a physical examination of the patient sufficient to enable the anaesthetist to evaluate the condition of the patient and to choose a suitable anaesthetic; and (b) entered or caused to be entered on the anaesthetic record and has authenticated the data relevant to administering the anaesthetic for the proposed procedure from the patient's history, laboratory findings and physical examination."

Preadmission clinics can serve a dual role, complying with the Public Hospitals Act and providing quality patient care, by providing a complete and accurate admission history and physical examination in addition to a focused preoperative assessment. The surgeon submits a note describing the history of the presenting complaint, the physical examination pertinent to the complaint and a statement of the planned surgical procedure. The review of systems, past history, including surgery and anaesthetics, medications, allergies, and social history are obtained from the preoperative questionnaire; completed by the patient and nurse. The healthcare professional in the PAC confirms the history and completes the physical examination which includes at least measurement of vital signs, airway examination, and examination of the respiratory and cardiovascular systems. In addition, the healthcare professional completes a physical examination of any other systems identified as a potential problem from the history, and pertinent to the overall safe conduct of the anaesthesia and surgery. The information provided by the patient, nurse, surgeon and healthcare professional in the PAC encompasses a complete history and physical examination, thereby complying with the requirements of the Public Hospitals Act.

Because of the diverse nature of surgery performed at different hospitals, it would be unreasonable to expect a single model for PACs. The design and staffing of the PAC will depend upon the nature of surgery performed, the patient population, and geographic location of the catchment area. Whether the hospital provides secondary or tertiary care and is community or university-based will also determine the design and staffing of the PAC. Regardless of the nature of the hospital, anaesthetists should be involved in the design, implementation, and administration of PACs to ensure an appropriate standard of care. ${ }^{9}$ The 
extent of anaesthesia involvement will vary from simply overseeing the direction and functions of the clinic to providing consultation services. ${ }^{1-4}$ Alternatively, anaesthesia may be required to provide a full time presence, such as in a tertiary care university setting. ${ }^{5}$

Preoperative assessments can, and are being provided by a variety of healthcare professionals. ${ }^{1-5}$ The design and staffing of PACs are determined by the nature of the surgical practice and the location and type of hospital where they exist. Anaesthetists must, however, be involved in overseeing and directing the preoperative evaluation process. The peri-operative period includes preoperative, intra-operative and post-operative care. Each of these segments of the peri-operative period are inter-related and have unique peculiarities related to patient care and costs. Anaesthetists alone have the information and experience to evaluate and minimise risk and cost related to the surgical experience and improve outcome. Anaesthesia involvement in PAC's not only improves patient care and maximises cost effective practice, it improves the stature of our specialty by demonstrating to the hospital community and the general public that the practice of anaesthesia is not limited to technical procedures, and does involve physicianpatient interactions and complex medical decision making. Both the ASA and CAS recognise the importance of the preoperative assessment and each have assigned Task Forces with a mandate to develop practice guidelines with regards to the preoperative assessment. There should be little doubt who these task forces will find ultimately responsible for the preoperative assessment.

\section{Qui est responsable de l'évaluation préopératoire ?}

Jusqu'à tout récemment, la tradition avait défini l'évaluation préopératoire comme une visite la veille de l'opération. Les progrès de la technologie médicale et la diminution des ressources attribuées à la santé ont fait croître de façon exponentielle l'ampleur de la chirurgie ambulatoire et le nombre d'admissions en chirurgie d'un jour. Dans ce champ d'activité, comme les interventions sont devenues plus complexes, elles requièrent plus de soins et mettent en évidence certaines carences dans l'élaboration de nos programmes opératoires. Les anesthésistes se retrouvent dans la position peu enviable de devoir abaisser leurs standards ou de changer leur façon d'exercer. En conséquence, les cliniques de préadmission (CPA) devraient améliorer la préparation préopératoire et augmenter l'efficacité des salles d'opération tout en maintenant le coût du séjour hospitalier à son minimum. Malheureusement, il n'existe pas de prototype de CPA et elles se présentent en autant de modèles qu'il y a de cliniques en existence. Toutefois, leur apparition a fait jaillir en grand nombre des questions et des sujets de préoccupation d'importance primordiale. Sans aucun doute, la question la plus tangible et la plus controversée de toutes est la suivante : qui est responsable de l'évaluation préopératoire ?

Dans le présent numéro du Journal, Shearer et al. ${ }^{1}$ décrivent un processus au cours duquel l'évaluation préopératoire se retrouve entre les mains d'omnipraticiens sans expérience anesthésique. Ces derniers deviennent responsables, dans un hôpital d'enseignement de 280 lits, de l'évaluation et du triage des patients programmés pour une chirurgie non urgente. La littérature a déjà révélé que des infirmières, ${ }^{2}$ des internistes, ${ }^{3}$ et des anesthésistes ${ }^{4,5}$ remplissent aussi ce rôle essentiel. De toute évidence, tout cela ne répond pas à la question essentielle: qui du personnel médical est le plus apte à jouer ce rôle ?

Avant aborder la question de la responsabilité de l'évaluation préopératoire, il faut d'abord définir ses objectifs. Premièrement, l'évaluation préopératoire procure au professionnel de la santé le moyen d'acquérir les renseignements médicaux pertinents (l'anamnèse et la documentation médicale), les consultations et les bilans de laboratoire pour déterminer si la période périopératoire présente une risque accru de mortalité et de morbidité. ${ }^{6}$ Deuxièmement, à l'aide des facteurs de risque identifiés, la condition médicale du parient doit être optimalisée et un plan de soins périopératoires élaboré. Finalement, l'évaluation préopératoire devrait diminuer l'anxiété du patient en lui fournissant l'opportunité de se renseigner sur le choix de l'anesthésie et sa prise en charge per- et postopératoire. ${ }^{6}$ Le risque périopératoire dépend de la condition préopératoire, l'importance de l'agression provoquée par l'intervention et le type d'anesthésie administrée. ${ }^{7}$ Le professionnel responsable de l'appréciation du risque doit connaitre les conditions médicales susceptibles d'augmenter la morbidité et la mortalité périopératoires et être capable de les identifier. Il doit aussi être en mesure de déterminer quand ces conditions nécessitent une investigation plus poussée, un traitement complémentaire ou des consultations spécialisées. Le professionnel en charge de l'évaluation préopératoire doit donc être familier avec le degré de gravité de l'agression chirurgicale et les changements physiopathologiques entrainés par la chirurgie et l'anesthésie, 
particulièrement ceux qui sont en rapport avec les systèmes respiratoire, cardiovasculaire et nerveux central. Finalement, les risques de morbidité et de mortalité inhérents à l'anesthésie elle-même doivent être identifiés et réduits au minimum.

Comme les patients qui se présentent en chirurgie n'ont pas tous besoin d'une évaluation préopératoire, l'essentiel de la recherche sur cette démarche doit être dirigé vers l'élaboration de méthodes de classification 'approprićes pour le triage des patients qui devront être évalués par un anesthésiste avant la journée de l'intervention. Présentement, il n'existe pas de méthode de dépistage applicable à tous les types de procédures anesthésiques. Le mécanisme idéal de dépistage devrait identifier tous les patients qui ont besoin d'une évaluation préopératoire et exclurent ceux qui n'en n'ont pas besoin. Au début des années 1980, avec l'introduction de la chirurgie ambulatoire, les anesthésistes se sont mis d'accord sur le fait que la visite préopératoire de l'anesthésiste le jour de la chirurgie représentait un standard approprié pour les patients en bonne santé soumis à une chirurgie mineure. Le chirurgien avait la responsabilité de voir à ce que les épreuves de laboratoire appropriées ainsi que l'anamnèse et l'examen physique figurent au dossier avant cette visite. Cette pratique était et demeure acceptable pour les patients en bonne santé qui se présentent pour une intervention mineure. En réalité, la mise en fonction des CPA ne doit être interprétée comme une obligation de produire une histoire et un examen physique pour tous les patients qui se présentent en chirurgie. Ceci serait de toute évidence abuser des fonds destinés aux soins de santé en déplaçant la responsabilité de l'anamnèse et de l'examen physique du chirurgien à d'autres professionnels à un coût accru pour le système de santé. Cependant, les patients à problèmes et ceux qui doivent subir des interventions majeures ont besoin d'une évaluation préopératoire avant le jour de l'intervention. Parce que le personnel chirurgical sur place est maintenant incapable de compléter l'histoire et l'examen clinique au moment de l'admission, un nombre considérable d'anesthésistes ont présumé incorrectement que l'évaluation préopératoire n'était composée que de l'histoire et de l'examen physique soumis par le chirurgien. Pour cette raison, plusieurs anesthésistes ont refusé de collaborer aux CPA. Pourtant, l'évaluation préopératoire à des objectifs précis : aborder les problèmes pertinents à l'administration de l'anesthésie et à la réalisation de la chirurgie. Une histoire et un examen clinique par d'autres professionnels de la santé ne constitue pas un sauf-conduit pour la sécurité de l'administration de l'anesthésie.?

Toute l'agitation soulevée par le problème de l'histoire et de l'examen clinique provient des règlements et statuts hospitaliers concernant les soins. Chaque province a ses statuts et règlements qui régissent l'exercice de la médecine. Les médecins et les chirurgiens doivent connaitre ceux qui s'appliquent à leur propre province, particulièrement ceux qui comportent des modifications récentes qui peuvent influencer leur façon d'exercer. En Ontario, le Public Hospital Act établit que :

«Le conseil doit s'assurer qu'un médecin (a) rédige l'anamnèse, (b) examine le patient et (c) porte un diagnostic provisoire sur la condition du patient et (d) l'inscrit au dossier du patient dans les 72 heures qui suivent son admission à l'hôpital..” ${ }^{8}$

«Aucun chirurgien ne doit intervenir sur un patient à moins qu'il n'ait (a) examiné le patient suffisamment pour être capable de porter un diagnostic; et (b) inscrit à son dossier les données de l'examen physique et le diagnostic». ${ }^{8}$

«Personne ne doit administrer une anesthésie générale, rachidienne ou épidurale ou une anesthésie intraveineuse ou un bloc régional autre que le bloc du nerf maxillaire pour une intervention dentaire à un patient hospitalisé ou ambulant à moins que (a) une histoire de sa maladie actuelle ou de son incapacité ou une histoire antérieure pertinente à sa maladie ou à son incapacité; ...(c) les données de l'examen physique du patient ; et (d) les résultats des épreuves de laboratoire concernant le patient considérés nécessaires par le médecin traitant ou le dentiste ne soient inscrits à son dossier». ${ }^{8}$ En outre, "personne ne doit administrer une anesthésie générale, rachidienne oui épidurale ou une anesthésie intraveineuse ou un bloc régional autre que le bloc du nerf maxillaire pour une intervention dentaire à un patient, à moins que l'anesthésiste n'ait (a) recueilli l'anamnèse et procédé à un examen physique suffisant pour lui permettre d'évaluer la condition du patient et de choisir un anesthésique approprié ; et (b) enregistré ou fait enregistrer sur le dossier anesthésique et authentifié les données pertinentes à l'administration de l'anesthésie pour l'intervention proposée à partir de l'anamnèse, du bilan de laboratoire et de l'examen physique». 8

Les cliniques de préadmission ont une double mission : se conformer au Public Hospitals Act et procurer des soins de qualité en produisant au moment de l'admission une histoire et un examen physique en plus d'une évaluation préopératoire spécifique. Le chirurgien rédige une note décrivant l'historique de la maladic actuelle, l'examen physique pertinent à celle-ci et le plan de la chirurgie prévue. La revue des systèmes, l'histoire antérieure, incluant la chirurgie et l'anesthésie, la médication prescrite, les allergies et l'analyse sociale sont 
extraites du questionnaire préopératoire, complété par le patient en présence d'une infirmière. Le professionnel de la santé en devoir à la CPA vérifie l'histoire et complète l'examen physique qui comprend un minimum : l'enregistrement des signes vitaux, l'examen des voies aériennes et l'évaluation des systèmes respiratoire et cardiovasculaire. De plus le professionnel de la santé complète l'examen des autres systèmes identifiés comme causes de problèmes potentiels d'après l'histoire et pertinents à la sécurité de l'anesthésie et de la chirurgie. L'information fournie par le patient, l'infirmière et le professionnel à la CPA parachèvent l'anamnèse et l'examen physique complets en conformité avec les exigences du Public Hospital Act.

A cause de la diversité des interventions effectuées dans les différents hôpitaux, il est déraisonnable d'anticiper un seul modèle de CPA. La conception et le l'attribution du personnel à la CPA dépendra de la nature de la chirurgie exécutée, de la population desservie, et de sa situation géographique. L'orientation vers des soins secondaires ou tertiaires ou la vocation communautaire ou universitaire de l'hôpital détermineront aussi la conception et l'attribution de son personnel. Indépendamment de la vocation de l'hôpital, les anesthésistes doivent participer à la conception, à la mise en marche, et à l'administration de la CPA pour assurer que les soins sont conformes à des normes valides. ${ }^{9}$ L'étendue de la participation des anesthésistes variera entre une simple surveillance de la gestion et du fonctionnement de la clinique à la prestation de services de consultation. ${ }^{1-4}$ En alternance, le département d'anesthésie pourrait être appelé à procurer une contribution à temps plein, par exemple, dans le cadre d'un hôpital universitaire de soins tertiaires. ${ }^{5}$

Actuellement, différents professionnels prennent en charge l'évaluation préopératoire. ${ }^{1-5}$ La conception de la CPA et l'attribution de son personnel sont déterminées par la nature de la chirurgie et l'endroit et le type d'hôpital où se trouve la clinique. Les anesthésistes doivent cependant participer activement au contrôle et à la gestion du processus d'évaluation préopératoire. La période périopératoire inclut les soins préopératoires, peropératoires et postopératoires. Chacun des segments de la période périopératoire à l'admission sont reliés entre eux et ont des propriétés uniques en relation avec les soins et les coûts. Seuls les anesthésistes possèdent les connaissances et l'expérience nécessaires à l'évaluation et à la minimalisation des risques et des coûts propres à la chirurgie, et seuls ils sont capables d'améliorer les résultats. La participation des anesthésistes aux CPA améliore la qualité des soins et diminue au minimum les coûts sans atteinte à l'efficacité. En outre, elle améliore la stature de notre discipline en démontrant au personnel hospitalier et au public en général que l'exercice de l'anesthésie ne se limite pas à des manoeuvres techniques, mais implique des interactions entre médecins et patients et permet de prendre des décisions médicales complexes. L'ASA et la SCA reconnaissent toutes deux l'importance de l'évaluation préopératoire et elles ont mandaté des groupes de travail ad hoc qui devront élaborer des lignes de conduites sur l'évaluation préopératoire. On peut facilement concevoir qui ces groupes de travail choisiront pour prendre charge de l'évaluation préopératoire.

\section{References}

1 Shearer W, Monagle J, Micbaels M. A model of community based, preadmission management for elective surgical patients. Can J Anaesth 1997; 44: 1311-14.

2 Hurtado C, Chung F, Krishnathas A. Does the nurse practitioner have a role in the Pre-Admission Unit? Can J Anaesth 1996; 43: A61B.

3 Badner NH, Craen RA, Paul TL, Doyle JA. Anaesthesia preadmission assessment. A new approach through use of a screening tool. Can J Anaesth 1997; 44: A70B.

4 Conway JB, Goldberg J, Chung F. Preadmission anaesthesia consultation clinic. Can J Anaesth 1992; 39: 1051-7.

5 Fischer SP. Development and effectiveness of an anesthetic preoperative evaluation clinic in a teaching hospital. Anesthesiology 1996; 85: 196-206.

6 Roizen MF. Preoperative evaluation. In: Miller RD (Ed.). Anesthesia, 4th ed. Vol 1. New York: Churchill Livingstone Inc., 1994: 827-82.

7 Pasternak LR. Preanesthesia evaluation of the surgical patient. ASA Refresher Courses in Anesthesiology 1996; 24: 205-19.

8 Ontario Laws and Statutes. Public Hospitals Act Revised Statutes of Ontario 1990 Chapter P.40 as amended by: 1996 Chapter 1, Sched. F, ss. 3-15 April 1996; Reg. 965 R4.7-8.

9 Finegan BA. Preadmission and outpatient consultation clinics (Editorial). Can J Anaesth 1992; 39: 1009-11. 